\title{
Penentuan Umur Simpan Ikan Roa Asap (Ikan Julung-Julung Asap) (Hemirhampus Sp) Menggunakan Metode ASLT (Accelerated Shelf Life Testing) Dengan Pendekatan Arrhenius
}

\author{
Ismail Harjan*1, Hamidin Rasulu ${ }^{2}$, Erna Rusliana M Saleh ${ }^{3}$ \\ 1, 2,3 Program Studi THP-Fakultas Pertanian Universitas Khairun Ternate \\ ${ }^{*}$ Corresponding Author: isamail22harjan@gmail.com \\ Manuscript received: 14-03-2018 Revision accepted: 02-05-2018
}

\begin{abstract}
Abstrak
Ikan julung-julung (Hemirhamphus far) atau ikan roa yang oleh masyarakat diolah secara tradisional dengan cara pengasapan, dikenal dengan nama Ikan Tore. Penelitian ini bertujuan untuk menduga umur simpan produk Ikan Julung-Julung Asap menggunakan metode ASLT dengan pendekatan Arrhenius. Penelitian ini dilakukan 2 tahap yaitu: tahap pertama proses pengasapan ikan julung dan tahap kedua analisis pendugaan umur simpan dilakukan dengan metode Accelerated Shelf-life Testing (ASLT). Parameter kadaluarsa yang diamati adalah organoleptik (warna, aroma dan rasa), Total Mikroba, Kadar Air dan $\mathrm{pH}$. Produk pangan disimpan pada lingkungan yang menyebabkannya cepat rusak (suhu atau kelembaban ruang penyimpanan yang lebih tinggi). Data perubahan mutu selama penyimpanan diubah dalam bentuk model matematika, kemudian umur simpan ditentukan dengan cara ekstrapolasi persamaan pada kondisi penyimpanan normal. Metode akselerasi dapat dilakukan dalam waktu yang lebih singkat dengan akurasi yang baik. Hasil penelitian menunjukkan bahwa perhitungan umur simpan ikan roa asap (ikan julung-julung asap) pada parameter kadar air memiliki energi aktivasi terendah, yaitu $-3417,91 \mathrm{kal} / \mathrm{mol}$ dan $\mathrm{R}^{2}=0,987$. Umur simpan ikan roa asap (ikan julung-julung asap) pada suhu $30^{\circ} \mathrm{C}$ diperoleh selama 2 bulan 8 hari, suhu $40^{\circ} \mathrm{C}$ selama 4 bulan 3 hari dan suhu $50^{\circ} \mathrm{C}$ mengalami peningkatan umur simpan adalah 7 bulan 4 hari.
\end{abstract}

Kata kunci: ASLT, Arrhenius, Ikan Roa, Umur simpan

\begin{abstract}
Julung fish (Hemirhamphus far) or fish roa that society has traditional way by evaporation, known as Tore fish. This study aims to estimate the shelf life of the product garfish ASLT Smoke using the Arrhenius approach. This study was conducted in 2 phases: the first phase is curing the grafish and the second phase is shelf life prediction Accelerated Shelf-life Testing (ASLT). Expiration parameter measure were (color, aroma and flavor), Total Microbe, Moisture and $\mathrm{pH}$. Food product stored in an area that causes rapid deterioration (temperature or humidity higher storage space). Data quality changes during storage changed into a mathematical model, then the shelf life is determined by extrapolation equation under normal storage conditions. Acceleration method can be done in a shorter time with good accuracy. The research results indicated that the calculation of the shelf life of smoked fish roa (julung fish smoke) on parameters of moisture content has the lowest activation energy, wich is $-3,417.91 \mathrm{cal} / \mathrm{mol}$ and $\mathrm{R}^{2}=0.987$. Roa smoke shelf life of fish ( julung fish smoke) at $30^{\circ} \mathrm{C}$ during 2 months, 8 days, a temperature of $40^{\circ} \mathrm{C}$ for 4 months, 3 days and a temperature of $50^{\circ} \mathrm{C}$ increased shelf life is 7 months, 4 days.
\end{abstract}

Keywords: ASLT, Arrhenius, Fish Roa, Age store 


\title{
PENDAHULUAN
}

Ikan julung-julung (Hemirhamphus far) atau ikan roa yang oleh masyarakat diolah secara tradisional dengan cara pengasapan, yang dikenal dengan nama Ikan Tore. Berdasarkan data Dinas Kelautan dan Perikanan Provinsi Maluku Utara (2012), perkembangan produksi ikan julung-julung lima tahun terakhir cenderung menurun yakni tahun 2007 sebesar 3.741,30 ton menjadi 1.316,00 ton pada tahun 2011. Umur simpan secara umum mengandung pengertian rentang waktu antara saat produk mulai dikemas atau diproduksi dengan saat mulai digunakan dengan mutu produk masih memenuhi syarat dikonsumsi (Hine, 1987).

Pendugaan umur simpan dapat dilakukan dengan metode konvensional dan metode akselerasi. Metode akselerasi dapat dilakukan dalam waktu relatif singkat pada kondisi ekstrim namun tetap memiliki ketepatan dan akurasi yang tepat (Arpah 2001).

Metode akselerasi dapat dilakukan dengan pendekatan model Arrhenius dan model kadar air kritis. Model Arrhenius biasanya digunakan untuk produk yang sensitif terhadap perubahan suhu penyimpanan sedangkan model kadar air kritis biasanya digunakan untuk produk yang mudah rusak karena penyerapan air dari lingkungan selama penyimpanan (Kusnandar 2006).

Model Arrhenius umumnya digunakan untuk menduga umur simpan produk pangan yang sensitif terhadap perubahan suhu, diantaranya produk pangan yang mudah mengalami ketengikan (oksidasi lemak), perubahan warna oleh reaksi pencoklatan, atau kerusakan vitamin C. Prinsip model Arrhenius adalah menyimpan produk pangan pada suhu ekstrim, dimana produk pangan akan lebih cepat rusak, kemudian umur simpan produk ditentukan berdasarkan ekstrapolasi ke suhu penyimpanan (Arpah, 2001).

\section{METODE PENELITIAN}

Penelitian ini dilaksanakan dari bulan April sampai bulan Mei tahun 2016. Penelitian ini dilakukan dalam dua tahap. Tahap pertama tahap pengasapan dilaksanakan di desa Sangowo Kecamatan Morotai Timur Kab. Pulau Moraotai. Tahap kedua adalah uji umur simpan dilakukan di Laboratorium Dasar Unkhair dan Laboratorium Kesehatan Ikan dan Lingkungan Fakultas Perikanan dan Ilmu Kelautan, kampus II Unkhair. Kelurahan Gambesi Kecamatan Kota Ternate Selatan Provinsi Maluku Utara.

\begin{abstract}
Alat dan Bahan
Alat pengasapan adalah anyaman bambu untuk penjepit ikan, alat untuk pengujian organoleptik adalah alat tulis, nampan. Alat untuk pengujian TPC adalah timbangan, autoclave, inkubator, cawan petri, botol pengencer, alat penghitung koloni, pipet, dan gelas. Alat untuk pengujian kadar air adalah blender, cawan porselin, alat penjepit/tang, desikator, sendok, timbangan analitik, oven. Alat untuk pengukuran $\mathrm{pH}$ adalah $\mathrm{pH}$ meter. Bahan baku yang digunakan pada penelitian ini adalah ikan roa (ikan julung-julung) (Hemiramphus sp.) dari desa Sangowo, Kec. Morotai Timur, Kab. Pulau Morotai Maluku Utara. Bahan yang digunakan untuk analisa laboratorium, aquades, NA (Nutrien Agar).
\end{abstract}

\section{Tahapan Penilitian}

Penelitian ini dilakukan 2 tahap yaitu: tahap pertama proses pengasapan ikan Roa (ikan Julung-Julung) dan tahap kedua analisis pendugaan umur simpan dilakukan dengan metode 
Accelerated Shelf-life Testing (ASLT). Parameter kadaluarsa yang diamati adalah organoleptik (warna, aroma dan rasa), total mikroba, kadar air dan $\mathrm{pH}$.

Pendugaan umur simpan dengan metode ASLT pada prinsipnya sangat bertumpu pada model Arrhenius, yaitu upaya mempercepat penurunan umur simpan dengan meningkatkan suhu secara terukur. Suhu penyimpanan yang digunakan yaitu suhu kamar $\left(30^{\circ} \mathrm{C}\right), 40^{\circ} \mathrm{C}$, dan $50{ }^{\circ} \mathrm{C}$.

Penentuan parameter kunci dengan melihat parameter yang mempunyai energi aktivasi terendah dan $\mathrm{R}^{2}>0,95$. Umur simpan ikan julung-julung asap dihitung dengan persamaan kinetika reaksi berdasarkan orde reaksinya.

$$
\begin{aligned}
& \mathrm{t}=\left(\mathrm{A}_{\mathrm{o}}-\mathrm{A}_{\mathrm{t}}\right) / \mathrm{k} \text {. } \\
& \text { (pers.orde nol) } \\
& \mathrm{t}=\ln \left(\mathrm{A}_{\mathrm{o}}-\mathrm{A}_{\mathrm{t}}\right) / \mathrm{k} \ldots \ldots \ldots \ldots \ldots \ldots \ldots \ldots \ldots \ldots . . . . . . . . . . . . .(\text { pers.orde } \mathrm{satu}) \\
& \text { dengan: } \\
& \mathrm{t} \text { = Umur simpan produk (hari/bulan), } \\
& \text { Ao }=\text { Nilai atribut mutu di awal (hari ke 0), } \\
& A_{t}=\text { Nilai atribut mutu diakhir (hari ke-t), dan } \\
& \mathrm{k}=\text { konstanta penurunan mutu. }
\end{aligned}
$$

Berikut berikut ini adalah persamaan arrhenius :

Dimana :

$$
k=k 0 . \mathrm{e}\left(-\frac{E a}{R T}\right)
$$

$\mathrm{K}$ = konstanta laju perubahan mutu

$\mathrm{K}_{\mathrm{o}}=$ konstanta ( faktor frekuensi yang tidak tergantung suhu)

Ea $=$ Energi aktivasi

$\mathrm{T}=$ suhu mutlak

$\mathrm{e}=$ logaritma dasar $(2,718282)$

$\mathrm{R}=$ konstanta gas $(8,314 \mathrm{~J} / \mathrm{mol} . \mathrm{K}=1.986 \mathrm{kal} / \mathrm{mol} . \mathrm{K})$

\section{Analisis Data}

\section{a. Rancangan Penentuan Umur Simpan Ikan Roa (Ikan Julung Asap) dengan model Arrhenius}

1. Ikan Roa Asap (Julung asap) sebanyak 450 gram kemudian dikelompokkan menjadi 3 bagian masing-masing 150 gram dan disimpan pada suhu kamar, $40^{\circ} \mathrm{C}$, dan $50^{\circ} \mathrm{C}$.

2. Pengamatan parameter mutu meliputi, warna, aroma, rasa, total mikroba, kadar air dan $\mathrm{pH}$. Setiap 5 hari sekali dilakukan pengamatan, sehingga skala organoleptik bernilai $<7$.

3. Data hasil analisa produk terhadap waktu diplotkan dan dihitung persamaan regresi liniernya. Kemudian diperoleh tiga persamaan regresi untuk tiga kondisi suhu penyimpanan produk dengan menggunakan $Y=a+b x$, dimana $Y=$ nilai karakteristik ikan roa asap (ikan julung asap), $X=$ lama waktu penyimpanan (hari), $a=$ nilai karakteristik ikan julung asap pada awal penyimpanan, $b=$ laju perubahan nilai karakteristik (nilai b sama dengan nilai $\mathrm{k}$ ).

4. Dari masing-masing persamaan tersebut diperoleh nilai slope (b) yang merupakan konstanta laju reaksi perubahan karakteristik produk atau laju penurunan mutu (k).

5. Untuk menentukan orde reaksi yang digunakan dibuat grafik orde nol yaitu hubungan antara nilai $\mathrm{k}$ dengan lama penyimpanan dan orde satu yaitu hubungan antara $\ln \mathrm{k}$ 
dengan lama penyimpanan. Dari kedua persamaan tersebut dipilih orde reaksi yang mempunyai nilai $\mathrm{R}^{2}$ terbesar.

6. Untuk pendekatan Arrhenius, nilai k diplotkan terhadap 1/T (K-1) dan ln k didapatkan nilai intersep dan slope dari persamaan regresi linier $\ln k=\ln k_{0}-(E / R)(1 / T)$, dimana $\ln$ $\mathrm{k}_{0}=$ intersep, $\mathrm{E} / \mathrm{R}=$ slope, $\mathrm{E}=$ energi aktivasi dan $\mathrm{R}=$ konstanta gas ideal $=1,986 \mathrm{kal} / \mathrm{mol}$ ${ }^{0} \mathrm{~K}$.

7. Dari persamaan pada tahap 5 diperoleh nilai konstanta $k_{0}$ yang merupakan faktor preeksponensial dan nilai energi aktivasi reaksi perubahan karakteristik ikan julungjulung asap $(\mathrm{Ea}=\mathrm{E})$. Dan kemudian ditentukan model persamaan laju reaksi $(\mathrm{k})$ perubahan karakteristik ikan julung asap dengan $\mathrm{k}=\mathrm{k}_{0} \cdot \mathrm{e}^{-\mathrm{E} / \mathrm{RT}}$ dengan $\mathrm{T}$ adalah suhu penyimpanan, misalnya: suhu ruang $=30^{\circ} \mathrm{C}$. Persamaan ini disebut sebagai persamaan Arrhenius.

8. Dengan persamaan Arrhenius dapat dihitung nilai konstanta Arrhenius (k) pada suhu (T) penyimpangan yang ditentukan.

9. Penentuan parameter kunci dengan melihat parameter yang mempunyai energi aktivasi terendah dan $\mathrm{R}^{2}$ tertinggi $(>0,95)$

10. Umur simpan ikan roa asap (julung-julung asap) dihitung dengan menggunakan persamaan kinetika reaksi berdasarkan orde reaksinya, yaitu jika reaksi berlangsung pada orde nol maka persamaan reaksinya adalah $\mathrm{A}_{\mathrm{t}}=\mathrm{A}_{0}-\mathrm{kt}$, sedangkan jika menggunakan orde satu maka persamaannya adalah $\ln A=\ln A_{0}-k t$, dimana $A$ adalah konsentrasi A pada akhir umur simpan dan t adalah umur simpan.

11. Untuk penentuan umur simpan pada suhu ruang adalah dengan memasukkan nilai suhu $\left(30^{\circ} \mathrm{C}=303^{\circ} \mathrm{K}\right)$ di dalam persamaan $\ln \mathrm{k}=\ln \mathrm{k}_{0}-(\mathrm{E} / \mathrm{R})(1 / \mathrm{T})$ dan didapat nilai $\mathrm{k}$, kemudian nilai $\mathrm{k}$ dimasukkan ke dalam persamaan orde reaksi untuk mendapatkan umur simpan ikan julung asap.

\section{HASIL DAN PEMBAHASAN}

Penentuan mutu Ikan Julung-Julung Asap dilakukan dengan penyimpanan pada tiga kondisi suhu berbeda yaitu, suhu ruang $\left(30^{\circ} \mathrm{C}\right), 40^{\circ} \mathrm{C}$ dan $50^{\circ} \mathrm{C}$. Untuk menentukan nilai mutu akhir ikan julung-julung asap $\left(\mathrm{A}_{\mathrm{t}}\right)$, dilakukan penyimpanan pada suhu lebih tinggi daripada suhu ruang yaitu pada suhu $50^{\circ} \mathrm{C}$ dan diamati secara berkala setiap 5 hari sekali hingga $\leq 60 \%$ panelis menolak produk sesuai dengan SNI No. 01-2725-2009 pada skala ratarata tidak suka (3) (Tabel 1).

Tabel 1. Rerata Uji Penerimaan Produk Ikan Julung-Julung Asap Selama Penyimpanan pada Suhu $\left(50^{\circ} \mathrm{C}\right)$

\begin{tabular}{|c|c|c|c|c|c|}
\hline \multirow[b]{2}{*}{ Hari ke } & \multicolumn{3}{|c|}{ Parameter (Skala 1-9) } & \multirow{2}{*}{$\begin{array}{c}\% \\
\text { menerima }\end{array}$} & \multirow{2}{*}{$\begin{array}{c}\% \\
\text { menolak }\end{array}$} \\
\hline & Warna & Aroma & Rasa & & \\
\hline 0 & 7,5 & 7,4 & 7,1 & 70 & 30 \\
\hline 5 & 5,7 & 6,5 & 5,9 & 65 & 35 \\
\hline 10 & 4,2 & 6 & 5,1 & 60 & 40 \\
\hline 15 & 4,2 & 5,1 & 5,1 & 50 & 50 \\
\hline 20 & 3,2 & 4,6 & 4,6 & 40 & 60 \\
\hline 25 & 2,9 & 3,6 & 3,7 & 35 & 65 \\
\hline 30 & 2,6 & 3,1 & 2,9 & 30 & 70 \\
\hline 35 & 1,5 & 2,4 & 1,7 & 20 & 80 \\
\hline
\end{tabular}


Tabel 1 menunjukkan bahwa waktu penyimpanan sangat berpengaruh terhadap penerimaan konsumen, semakin lama waktu penyimpanan penerimaan konsumen terhadap ikan Roa (ikan julung-julung asap) semakin menurun.

\section{WARNA}

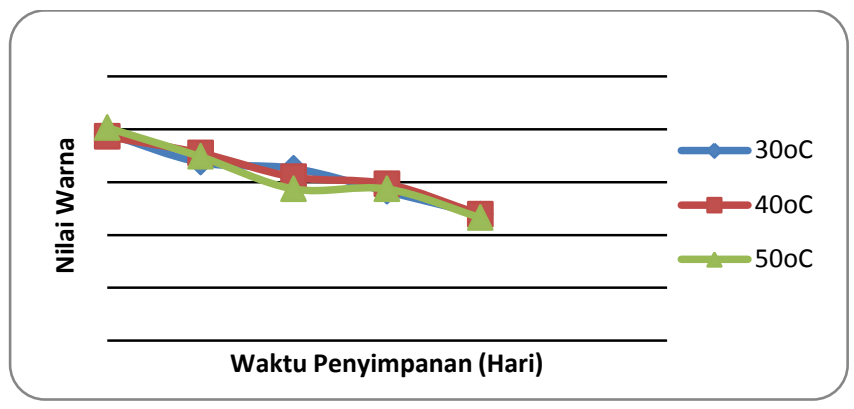

Gambar 1. Grafik Perubahan Nilai Warna pada Tiga Kondisi Suhu Penyimpanan

Berdasarkan Gambar 1 terlihat adanya penurunan kesukaan terhadap warna ikan julungjulung asap selama penyimpanan. Menurut Moeljianto (1992), warna ideal dari ikan hasil proses pengasapan adalah warna kuning emas kecoklatan. Pada penelitian ini lama penyimpanan 20 hari nilai organoleptik mencapai angka 3 skala organoleptik.

Tabel 2. Persamaan Regresi Linier Untuk Parameter Warna Orde Nol Dan Orde Satu Pada Ikan Roa asap (Julung-Julung Asap)

\begin{tabular}{|l|c|c|c|c|}
\hline SUHU & \multicolumn{2}{|c|}{ Persamaan Regresi Linear } & \multicolumn{2}{|c|}{ R2 } \\
\hline (T) ${ }^{\circ} \mathrm{C}$ & ORDE 0 & ORDE 1 & ORDE 0 & ORDE 1 \\
\hline 30 & $\mathrm{y}=-0,178 \mathrm{x}+6,78$ & $\mathrm{y}=-0,036 \mathrm{x}+1,937$ & 0,956 & 0,973 \\
\hline 40 & $\mathrm{y}=-0,174 \mathrm{x}+6,78$ & $\mathrm{y}=-0,035 \mathrm{x}+1,939$ & 0,976 & 0,973 \\
\hline 50 & $\mathrm{y}=-0,202 \mathrm{x}+6,98$ & $\mathrm{y}=-0,040 \mathrm{x}+1,959$ & 0,906 & 0,942 \\
\hline
\end{tabular}

Persaman regresi linear dapat dilihat pada Tabel 2 terlihat bahwa $\left(\mathrm{R}^{2}\right.$ orde satu $\left.>\mathrm{R}^{2}{ }_{\text {orde nol }}\right)$ maka penurunan nilai warna mengikuti reaksi orde satu.

\section{Aroma}

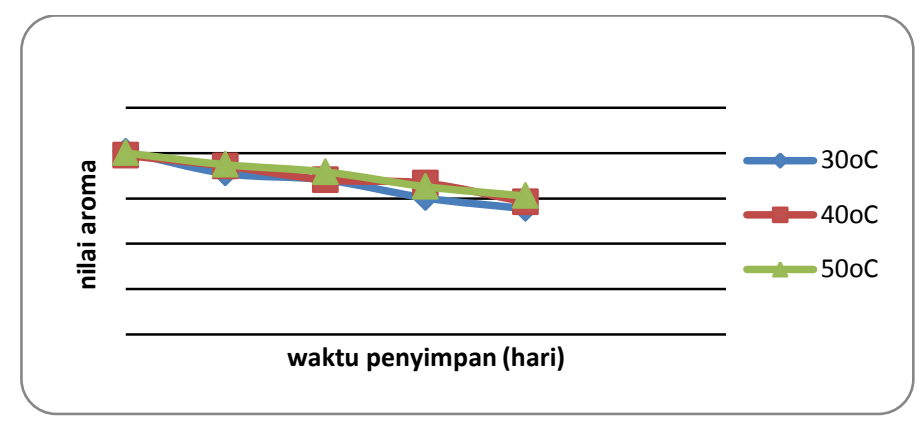

Gambar 2. Grafik Perubahan Nilai Aroma Pada Tiga Kondisi Suhu Penyimpanan 
Berdasarkan Gambar 2 terlihat ikan Roa (julung-julung asap) pada suhu ruang lebih cepat mengalami kerusakan dari segi aroma dibandingkan ikan roa julung julung asap yang disimpan pada suhu $40^{\circ} \mathrm{C}$ dan $50^{\circ} \mathrm{C}$ berdasarkan skala organoleptik.

Tabel 3. Persamaan Regresi Linier Untuk Parameter Aroma Orde Nol dan Orde Satu Pada Ikan Roa (Julung-Julung Asap)

\begin{tabular}{c|c|c|c|c|}
\hline SUHU & \multicolumn{2}{|c|}{ Persamaan Regresi Linear } & \multicolumn{2}{c|}{$\mathrm{R} 2$} \\
(T) ${ }^{\circ} \mathrm{C}$ & ORDE 0 & ORDE 1 & ORDE 0 & ORDE 1 \\
\hline 30 & $\mathrm{y}=-0,168 \mathrm{x}+7,16$ & $\mathrm{y}=-0,030 \mathrm{x}+1,982$ & 0,952 & 0,977 \\
\hline 40 & $\mathrm{y}=-0,138 \mathrm{x}+7,12$ & $\mathrm{y}=-0,024 \mathrm{x}+1,976$ & 0,973 & 0,967 \\
\hline 50 & $\mathrm{y}=-0,140 \mathrm{x}+7,32$ & $\mathrm{y}=-0,023 \mathrm{x}+2,002$ & 0,99 & 0,992 \\
\hline
\end{tabular}

Persaman regresi linear dapat dilihat pada Tabel 3 nampak bahwa $\left(R^{2}{ }_{\text {orde satu }}>R^{2}\right.$ orde nol $)$ maka penurunan nilai aroma mengikuti reaksi orde satu.

\section{Rasa}

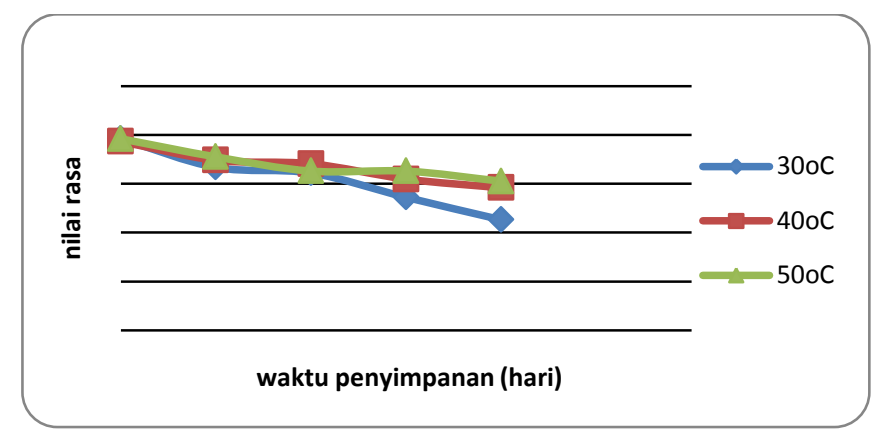

Gambar 3. Nilai Perubahan Rasa Pada Tiga Kondisi Suhu Penyimpanan

Berdasarkan Gambar 3 telihat Rasa ikan roa asap (ikan julung-julung asap) yang disimpan di suhu yang berbeda mengalami penurunan penerimaan selama penyimpanan. Hal ini diduga disebabkan oleh karena telah terjadi perubahan kimia, biokimia maupun mikrobiologi yang dapat mempengaruhi rasa produk tersebut.

Tabel 4. Persamaan Regresi Linier Untuk Parameter Rasa Orde Nol dan Orde Satu Pada Ikan Roa( Julung-Julung Asap).

\begin{tabular}{|l|c|c|c|c|}
\hline SUHU & \multicolumn{2}{|c|}{ Persamaan Regresi Linear } & \multicolumn{2}{|c|}{$\mathrm{R} 2$} \\
\hline (T) ${ }^{\circ} \mathrm{C}$ & ORDE 0 & ORDE 1 & ORDE 0 & ORDE 1 \\
\hline 30 & $\mathrm{y}=0,188 \mathrm{x}+6,76$ & $\mathrm{y}=-0,039 \mathrm{x}+1,938$ & 0,955 & 0,967 \\
\hline 40 & $\mathrm{y}=-0,124 \mathrm{x}+6,66$ & $\mathrm{y}=0,022+1,904$ & 0,949 & 0,973 \\
\hline 50 & $\mathrm{y}=-0,116 \mathrm{x}+6,72$ & $\mathrm{y}=0,020 \mathrm{x}+1,906$ & 0,877 & 0,905 \\
\hline
\end{tabular}

Persaman regresi linear parameter rasa dapat dilihat pada Tabel 4 nampak bahwa $\left(R^{2}\right.$ orde satu $>$ $\mathrm{R}^{2}$ orde nol) penurunan nilai rasa mengikuti reaksi orde satu. 


\section{Total Plate Count (TPC)}

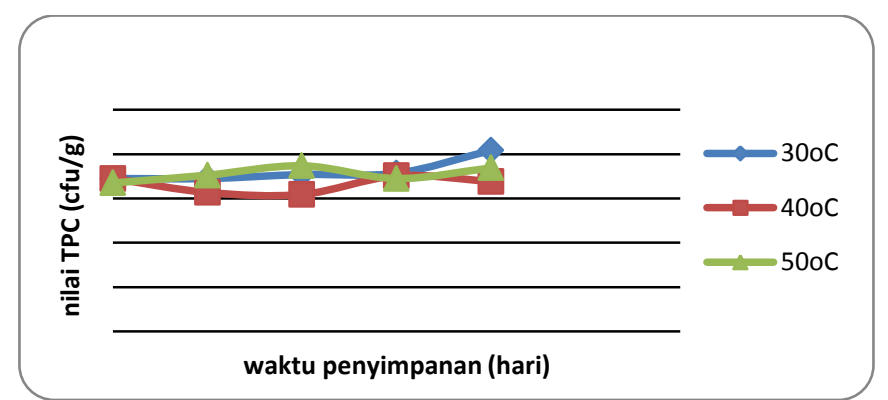

Gambar 4. Jumlah Total Mikroba Ikan Roa (Julung-Julung Asap) Pada Tiga Kondisi Suhu Penyimpanan

Berdasarkan Gambar 4 terlihat jumlah total mikroba selama penyimpanan ikan roa (julungjulung asap) pada suhu ruang terjadi peningkatan. Total mikroba setelah penyimpanan hari 0 pada suhu ruang $\left(30^{\circ} \mathrm{C}\right)$ yaitu $3,4 \mathrm{cfu} / \mathrm{g}$, meningkat pada hari ke 20 yaitu $4,08 \mathrm{cfu} / \mathrm{g}$. Sedangkan total mikroba setelah penyimpanan $40^{\circ} \mathrm{C} 3,4 \mathrm{CFU} / \mathrm{g}$ menurun menjadi $3,3 \mathrm{cfu} / \mathrm{g}$. Suhu $50^{\circ} \mathrm{C}$ yaitu $3,4 \mathrm{cfu} / \mathrm{g}$, meningkat pada hari ke 20 yaitu $3,68 \mathrm{cfu} / \mathrm{g}$.

Tabel 5. Persamaan Regresi Linier Untuk Parameter TPC Orde Nol dan Orde Satu Pada Ikan Julung-Julung Asap(ikan roa)

\begin{tabular}{|l|l|l|l|l|}
\hline \multirow{2}{*}{$\begin{array}{l}\text { SUHU } \\
(\mathrm{T}) \mathrm{C} C\end{array}$} & \multicolumn{2}{|c|}{ Persamaan Regresi Linear } & \multicolumn{2}{|c|}{$\mathrm{R} 2$} \\
\cline { 2 - 6 } & ORDE 0 & ORDE 1 & ORDE 0 & ORDE 1 \\
\hline 30 & $\mathrm{y}=1,2 \mathrm{x}+26,5$ & $\mathrm{y}=0,027 \mathrm{x}+3,341$ & 0,638 & 0,682 \\
\hline 40 & $\mathrm{y}=0,13 \mathrm{x}+26,6$ & $\mathrm{y}=0,004 \mathrm{x}+3,265$ & 0,04 & 0,041 \\
\hline 50 & $\mathrm{y}=0,41 \mathrm{x}+31,1$ & $\mathrm{y}=0,012 \mathrm{x}+3,430$ & 0,325 & 0,344 \\
\hline
\end{tabular}

Persaman regresi linear parameter total mikroba dapat dilihat pada Tabel 5 nampak bahwa $\left(\mathrm{R}^{2}\right.$ orde satu $>\mathrm{R}^{2}$ orde nol) makan nilai TPC mengikuti reaksi orde satu.

\section{Kadar Air}

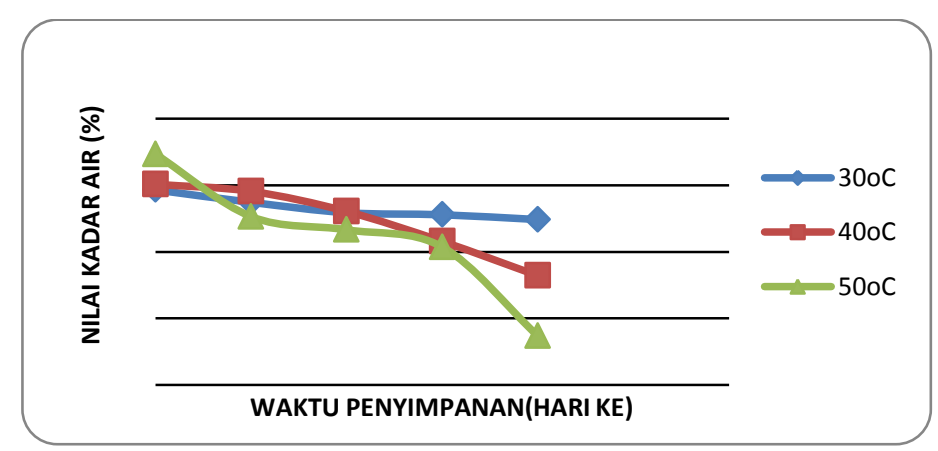

Gambar 5. Grafik Nilai Kadar Air Ikan Roa (Ikan julung-julung asap) pada Tiga Kondisi Suhu Penyimpanan

Berdasarkan Gambar 5 terlihat penurunan kadar air. Penurunan kadar air pada produk ikan roa (julung-julung asap) ini terjadi karena adanya interaksi antara produk dengan lingkungannya dimana terjadi proses penguapan akibat perbedaan suhu produk dengan suhu lingkungannya. 
Tabel 6. Persamaan Regresi Linier Untuk Parameter Kadar Air Orde Nol dan Orde Satu Pada Ikan Julung-Julung Asap

\begin{tabular}{l|l|l|c|c|}
\hline \multirow{2}{*}{\begin{tabular}{l} 
SUHU \\
\multirow{2}{*}{()$^{\circ} \mathrm{C}$}
\end{tabular}} & \multicolumn{2}{|c|}{ ORDE 0 } & ORDE 1 & \multicolumn{2}{c|}{$\mathrm{R}^{2}$} \\
\hline 30 & $\mathrm{y}=0,179 \mathrm{x}+5,749$ & $\mathrm{y}=0,0404 \mathrm{x}+1,752$ & 0,852 & 0,917 \\
\hline 40 & $\mathrm{y}=0,380 \mathrm{x}+7,604$ & $\mathrm{y}=0,0,140 \mathrm{x}+2,331$ & 0,975 & 0,947 \\
\hline 50 & $\mathrm{y}=0,786 \mathrm{x}+12,85$ & $\mathrm{y}=0,237+2,825$ & 0,63 & 0,901 \\
\hline
\end{tabular}

Persaman regresi linear parameter total mikroba dapat dilihat pada Tabel 6 nampak bahwa $\left(\mathrm{R}^{2}\right.$ orde satu $>\mathrm{R}^{2}$ orde nol $)$ makan nilai kadar air mengikuti reaksi orde satu.

\section{6. $\mathrm{pH}$}

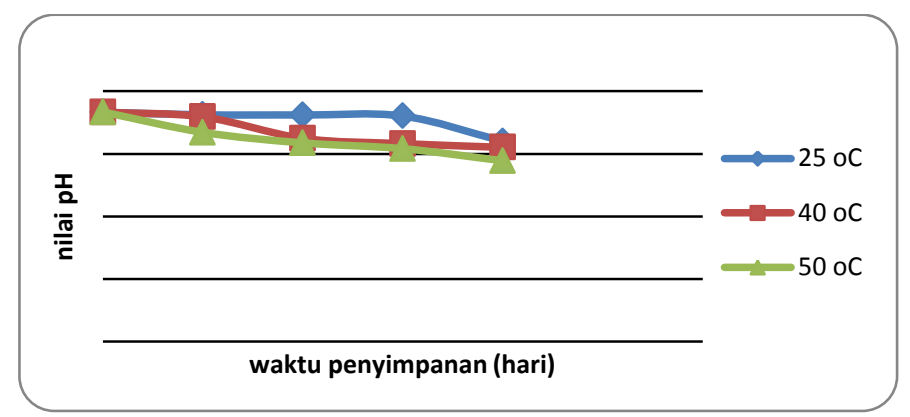

Gambar 15. Grafik Penurunan Nilai pH

Berdasarkan Gambar 15 terlihat selama penyimpanan mengalami penurunan. Hal ini disebabkan pada penyimpanan ikan julung-julung asap terjadi pemanasan dengan suhu berbeda sedang sehingga dapat menurunkan $\mathrm{pH}$, senyawa yang ada pada asap bersifat asam sehingga $\mathrm{pH}$ menjadi rendah (asam). Ketiga suhu penyimpanan terjadi perbedaan yang tidak begitu signifikan dikarenakan perbedaan suhu yang tidak begitu besar.

Tabel 7. Persamaan Regresi Linier Untuk Parameter pH Orde Nol dan Orde Satu Pada Ikan Roa (Julung-Julung Asap).

\begin{tabular}{|l|l|l|l|l|}
\hline $\begin{array}{c}\text { SUHU } \\
(\mathrm{T}){ }^{\circ} \mathrm{C}\end{array}$ & \multicolumn{2}{|c|}{ Persamaan Regresi Linear } & \multicolumn{2}{c|}{$\mathrm{R} 2$} \\
\cline { 2 - 5 } & ORDE 0 & ORDE 1 & ORDE 0 & ORDE 1 \\
\hline 30 & $\mathrm{y}=-0,052 \mathrm{x}+6,428$ & $\mathrm{y}=-0,009 \mathrm{x}+1,865$ & 0,62 & 0,608 \\
\hline 40 & $\mathrm{y}=-0,082 \mathrm{x}+6,228$ & $\mathrm{y}=-0,015 \mathrm{x}+1,831$ & 0,904 & 0,912 \\
\hline 50 & $\mathrm{y}=-0,093 \mathrm{x}+6,014$ & $\mathrm{y}=-0,018 \mathrm{x}+1,797$ & 0,932 & 0,956 \\
\hline
\end{tabular}

Persaman regresi linear parameter $\mathrm{pH}$ dapat dilihat pada Tabel 7 nampak bahwa $\left(\mathrm{R}^{2}\right.$ orde satu $>$ $\mathrm{R}^{2}$ orde nol) maka nilai $\mathrm{pH}$ mengikuti reaksi orde satu. 


\section{Pendugaan Umur Simpan}

Pada dasarnya diketahui bahwa laju reaksi sangat dipengaruhi oleh suhu. Dalam model Arrhenius suhu merupakan faktor yang sangat berpengaruh terhadap penurunan mutu produk pangan. Pendugaan umur simpan ikan julung-julung asap dihitung menggunakan persamaan regresi linear dari parameter yang memiliki nilai energi aktivasi terendah. Dari masing-masing persamaan diperoleh nilai $\mathrm{k}$ yang dapat digunakan untuk menghitung umur simpan produk. Nilai $\mathrm{k}$ diperoleh dari rumus $\mathrm{k}=\mathrm{ko}_{\mathrm{e}} \mathrm{e}^{-\mathrm{E} / \mathrm{RT}}$ dimana $\ln \mathrm{k}_{0}=$ intersep $\mathrm{Ea} / \mathrm{R}=$ slope. Nilai k yang diperoleh kemudian dimasukkan dalam persamaan kinetika reaksi berdasarkan orde reaksinya. Parameter nilai kadar air mengikuti kinetika reaksi orde 1, sehingga persamaan umur simpannya adalah:

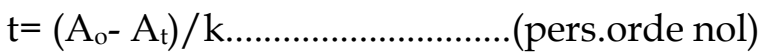

$$
\begin{aligned}
& \mathrm{t}=\ln \left(\mathrm{A}_{\mathrm{o}}-\mathrm{A}_{\mathrm{t}}\right) / \mathrm{k} \ldots \ldots \ldots \ldots \ldots \ldots \ldots \ldots \ldots \ldots . . .(\text { pers.orde } \mathrm{natu})
\end{aligned}
$$

Tabel 7. Persamaan Arrhenius dan Energi Aktivasi Setiap Parameter

\begin{tabular}{|c|c|c|c|c|}
\hline No & Parameter & Persamaan Arrhenius & $\begin{array}{c}\text { Energi } \\
\text { aktivasi } \\
\text { (Kal/mol) }\end{array}$ & $\mathrm{R}^{2}$ \\
\hline 1 & WARNA & $-5,887(1 / T)+246,8$ & 485,1798 & 0,987 \\
\hline 2 & AROMA & $-5,335(1 / T)+82,33$ & 163,5044 & 0,109 \\
\hline 3 & RASA & $-6,218(1 / T)+346,9$ & 688,9454 & 0,993 \\
\hline 4 & TPC & $-5,207(1 / T)+210,6$ & 418,2516 & 0,456 \\
\hline 5 & KADAR AIR & $0,316(1 / T)-1721$ & $-3417,91$ & 0,987 \\
\hline 6 & $\mathrm{pH}$ & $-6,811(1 / \mathrm{T})+520$ & 1032,919 & 1 \\
\hline
\end{tabular}

Diantara parameter tersebut dipilih satu parameter untuk menghitung umur simpan ikan julung-julung asap dimana parameter tersebut dianggap sangat mempengaruhi penurunan mutu ikan julung-julung asap selama penyimpanan. Parameter yang digunakan tersebut adalah parameter yang mempunyai nilai energi aktivasi terendah karena semakin rendah energi yang dibutuhkan untuk memulai reaksi kerusakan lebih rendah sehingga reaksi kerusakan akan berlangsung lebih lama.

Tabel 8. Penentuan Umur Simpan ikan julung-julung asap dengan Parameter Kadar Air

\begin{tabular}{|c|c|c|}
\hline SUHU $^{\circ} \mathrm{C}$ & UMUR SIMPAN (HARI) & UMUR SIMPAN \\
\hline 30 & 68,74 & 2Bulan 8 Hari \\
\hline 40 & 123,02 & 4 Bulan 3 Hari \\
\hline 50 & 214,58 & 7 Bulan 4 Hari \\
\hline
\end{tabular}

Metode ASLT suhu merupakan faktor kunci yang menentukan kerusakan makanan. Berdasarkan Tabel 19 dapat dilihat bahwa umur simpan produk ikan julung-julung asap pada masing-masing suhu penyimpanan berbeda. Pada suhu $30^{\circ} \mathrm{C}$ diperoleh umur simpan selama 2 bulan 8 hari, suhu $40^{\circ} \mathrm{C}$ selama 4 bulan 3 hari dan suhu $50^{\circ} \mathrm{C}$ adalah 7 bulan 4 hari. 
Hasil tersebut menunjukkan bahwa umur simpan ikan roa asap sangat dipengaruhi oleh kondisi $\mathrm{RH}$ di ruang Penyimpanan. Semakin tinggi $\mathrm{RH}$ maka semakin singkat umur simpannya, begitupun sebaliknya. Hal ini menjelaskan bahwa semakin tinggi laju penambahan air pada bahan dapat mengakibatkan laju penurunan mutu semakin cepat.

\section{KESIMPULAN DAN SARAN}

\section{KESIMPULAN}

Umur simpan ikan julung-julung asap diperoleh melalui parameter kadar air karena memiliki energi aktivasi paling rendah yaitu $-3417,91 \mathrm{kal} / \mathrm{mol}$ dan $\mathrm{R}^{2}=0,987$. Hasil perhitungan menunjukkan bahwa semakin tinggi suhu penyimpanan umur simpan produk semakin pendek, tetapi pada penelitian ini pada suhu $50^{\circ} \mathrm{C}$ umur simpannya lebih lama. Umur simpan ikan roa asap (ikan julung-julung asap) pada suhu $30^{\circ} \mathrm{C}$ diperoleh selama 2 bulan 8 hari, suhu $40^{\circ} \mathrm{C}$ selama 4 bulan 3 hari dan suhu $50^{\circ} \mathrm{C}$ mengalami peningkatan umur simpan adalah 7 bulan 4 hari.

\section{SARAN}

Saran yang perlu diberikan dalam penelitian ini adalah :

1. Perlu dilakuan pengujian umur simpan ikan julung-julung dalam kemasan.

2. Perlu dilakukan penentuan umur simpan ikan asap jenis lain.

\section{DATAR PUSTAKA}

Arpah M. 2001. Buku dan Monograf Penentuan Kadaluwarsa Produk Pangan. Bogor: Program Pascasarjana, Institut Pertanian Bogor.

Badan Standarisasi Nasional. 2006. Penentuan Kadar Air Produk Perikanan. SNI No. 01-2354.22006. Jakarta.

Badan Standarisasi Nasional.2009. Spesifikasi Ikan Asap. SNI No. 01-2725-2009. Jakarta.

Dinas Perikanan dan Kelautan Provinsi Maluku Utara. 2012. Statistik Perikanan Tangkap Provinsi Maluku Utara.

Fardiaz, S. 1992. Analisis Mikrobiologi Pangan. Liberty. Yogyakart.

Floros, J.D. and V. Gnanasekharan. 1993. Shelf Life Prediction of Packaged Foods: chemichal, biological, physical, and nutritional aspects. G. Chlaralambous (Ed.). Elsevier Publ.,London.

Hariyadi, P. 2004. Prinsip-prinsip pendugaan masa kedaluwarsa dengan metode Accelerated Shelf Life Test. Pelatihan Pendugaan Waktu Kedaluwarsa (Self Life). Pusat Studi Pangan dan Gizi: Institut Pertanian Bogor.

Haryati, Teti Estiasih, Feronika Heppy, Kgs Ahmadi, Jurnal Pangan dan Agroindustri Vol. 3 No 1 p.156-165, Januari 2015.Mojokerto.

Koswara, S. 2004. Evaluasi sensori dalam pendugaan umur simpan produk pangan. Pelatihan Pendugaan Waktu Kadaluwarsa (Self Life). Bogor, 1-2 Desember 2004. Pusat Studi Pangan dan Gizi, Institut Pertanian Bogor

Kusnandar F. 2006. Disain Percobaan Dalam Penetapan Umur Simpan Produk Pangan Dengan Metode ASLT (Model Arrhenius dan Kadar Air Kritis). Dalam: Modul Pelatihan: Pendugaan dan Pengendalian Masa Kadaluarsa Bahan dan Produk Pangan. Bogor. 
Moeljanto. R. 1987. Pengasapan dan Fermentasi Ikan. Penebar Swadaya. Jakarta.

Moeljanto. 1992. Pengawetan dan Pengolahan Hasil Perikanan. Penebar Swadaya. Jakarta.

Putri Lilasari dan Teti Estiasi. 2011. Penentuan Umur Simpan Jahe Instan dengan Metode Accelarated Shelf Life Test (ASLT) dengan Pendekatan Arrhenius

Wibowo, S. 1996. Industri Pengasapan Ikan. Penebar Swadaya. Jakarta.

Wibowo, S. 2000. Industri Pengasapan Ikan. Penebar Swadaya. Jakarta.

Winarno, F. G. 1993. Pangan dan Gizi. Gramedia Pustaka Utama. Jakarta.

Winarno, F. G. dan Jennie, B. S. L. 1983. Kerusakan Bahan Pangan. PT Gramedia Pustaka Utama, Jakarta.

Winarno, F.G., Fardiaz, S. 1980. Pengantar Teknologi Pangan. Penerbit PT. Gramedia. Jakarta. 